\title{
Corporate Governance: Determining of the Performance of Indonesia Companies
}

\author{
Adriyanti Agustina Putri ${ }^{1}$ Arumega Zarefar $^{2}$ \\ 1.Faculty Economic and Business, Universitas Muhammadiyah Riau, Pekanbaru 28156, Riau \\ 2.Faculty Economic and Business, Universitas Riau, Pekanbaru 28156, Riau
}

\begin{abstract}
The purpose if this study is to determine the effect of the implementation of corporate governance mechanisms, namely independent variables are considirng og the board of commissioners, managerial ownership, foreign ownership, debt financing, and audit quality. The dependent variable is company performance with control variables, which are company size and company age. The data used in this study are secondary data involving 103 companies listed on the Indonesia Stock Exchange fo rthe period 2015-2018. The dat aused in this study were analyzed using SPSS version 25. The results of this study show that: the board of commiccioners, managerial ownership, foreign ownership, debt financing and the only variable quality audit that affect the performance of company late while variable size and age of the company can not be a variable control of the performance of the company.
\end{abstract}

Keywords: Coporate Governance, Board of Commissioners, Managerial Ownership, Foreign Ownership, Debt Financing, Audit Quality, Company Size, Age, Company Performance.

DOI: $10.7176 /$ RJFA/11-4-06

Publication date: February $29^{\text {th }} 2020$

\section{Introduction}

The development of corporate governance in Indonesia began in 1997. From the economic crisis that had many consequences that could not be a voided, one of which was the weak national economic growth and the number of companies that had collapsed and unable to survive (Iskandar and Chamlou in Hidayah 2008). The financial crisis that occured in Southeast Asia and other countries is not only due to macroeconomic factors but the lack of good corporate governance in these countries as one of the cause of the economic crisis, the effecrs of which can still be felt to date.

Evidence shows the weak corporate governance practices in Indonesia lead to a deficiency in organizational decision making and corporate actions (Alijoyo at al, 1994 in Hastuti, 2011). According to Magdi and Nedareh (2002), corporate governance is how to run an organization in a way that ensures that owners or shareholders receive a fair return on their investment, while the expectations of other stakeholders are also met.

Five basic principles underlie the creation of corporate governance, namely transparency, accountability, responsibility, independence and fairness. Therefore, the existance of good governance is expected to reduce agency problems in a company basd on corporate goverance principles that ultimately corporate governance can be a tool to improve the performance of a company. Performance is a reflection of a company's ability to manage and allocate its resources. With a good company performance will attract investors to invest.

The are two types of corporate governance mechanisms namely internal mechanisms and external mechanisms (Juwitasari, 2008). Internal governance mechanisms relate to the board of commissioners, managerial ownership, foreign ownership, debt financing, company size, and company age (Hassan and Halbouni, 2013), while the external governance mechanism is related to the quality of auditors conducted by stakeholders outside the company management.

Board of commissioners as a company organ responsible for ensuring that compaies implement corporate governance good and collcetively monitoring and advising the board of dirctors (NCG, 2006). Indonesia adheres to a tow-tier board system which requires the Board of Directors as the manager and the Board of Commissioners is no longer possible to serve as a board of directors (Murhadi, 2009).

Also, according to Boediono (2005), besides that managerial ownership is the amount of share ownership managed by the management of all the company's share capital. To reduce the problem of fortune, it can be done by aligning the interests between the principal and the agent. With an increase in managerial ownership, the company's management will try to improve its performance to ensure the prosperity of shareholders. Cases cincerning corporate governance to date have still occured in Indonesia, such as in PT Kimia Farma (2002), PT Indo Farma (2004), or PT Waskita Karya (2009).

Ownership of shares by foreigners is shares owned by individuals, legal entities, the government and its parts having different statuses. Foreigners who have invested their shares in the country have a management system, tehcnoogy, innovation, expertise, and pretty good marketing that can provide a prositive influence on the perfirmance of the company (Qiranata and Nugrahanti, 2013).

Related to the debt financing structure as part of the corporate governance mechanism, debt is all of the 
company's financial obligations to other parties that have not been fulfilled from creditors. According to Weston and Brigham (1993:458), wisdom capital structure consists of choosing between the rate of returm and risk. The use of substantial debt means it can increase the risk level of the company's revenue stream, but using more debt can also increase the desired rate of return.

Also, audit quality can be realized if it can meet generally accepted audit standards. Audit standards are general guidelines to help auditors fulfill their professional responsibilities in auditing financial statements. This standard includes consideration of professional wualificantions such as competence and independence, reporting requirements, and evidence (Randal J et al., 2011). Research on audit quliaty was also carried out by Meutia (@004), who concluded that for companies that use larger public accounting firms (Big 4), the resulting audit quality is also better.

Size is aldo reflection of the size of the company. A larger company size indicates that the company's competitiveness is higher that its maincompetitors, and the values of the company will increase due to a positive response from investors.

Research on corporate governance that has influenced company performance has been carried out by researchers in Indonesia and outside Indonesia, with mixed results. From previous studies that prove diffrenet results, the authora are motivated to conduct further research on how corporate governance affects corporate performance, as measured by Tobin's Q.

\section{Theoretical Basis and Hypothesis Formulation}

\subsection{Agency Theory}

Agency theory or often called agency theory, expains the relationship between two parties, namely the owner (Principal) and management (agent). Jensen and Meckling (1976) tate agency relationships arise when one or more individuals (principals) pay other individuals (Employees or agents) to act on their behalf, delegating the power to make dicisions to agents of employees (Purwantini, 2011)>

In companies, corporate governance need to be applied. Corporate governance is a concept that is based on agency theory, so it is expected to provied confidence to investors that they will receive a return on the funds invested (Herawaty, 2008).

Corporate governance mechanisms can reduce agency problems, which can then improve company performance (Purno and Khafid, 2013). By providing proper monitoring and protection to shareholders, the performance of a company must practice good parctices as well (Haat et al., 2008).

\subsection{Company Performance}

Company performance is a measure of the company's ability to achiece company goals. The company's performance can be used as a benchmark assessment of the good or bad of a company. The company is said to be goof if the company's performance is excellent, and vice versa, if the company's performance is terrible, the the company is awful.

Whe linked with corporate governance, corporate governance is a driver of performance (Millstein et al., 1998; Keasey et al., 1997), in other words, the enforcement of corporate governance can encourage organizational performance (Trisnantari, 2012). The tool used o measure company performance is the company's financial statements. Financial statement are one of the media used to measure the longterm performance of a company.

Measurement of company performance in this tsudy uses the Tobin's Q ratio. Tboin's Q is a usedul indicator for measuring company performance, as seen from the way management manages company assets (Sudiyatno and Puspitasari, 2010).

\subsection{Board of Commissioners}

The board of commissioners is a vital component of internal governance that allows for the resolution of problems inherent in the institutions that manage the organization. FCGI (2001) explains that the board of commissioners plays a signifcant role in the company, especially in the implementation of corporate governance.

KNKG (2006) distinguishes the board of commissioners into two categories. The first is an independent board of commissioners, and the second is a non independent board of commissioners. An independent jury of commissioners if a commissioner that is not form an affiliated party with the company. While non-independent commissioners are commissioners who have an affiliation with the company. Affiliated is a party that has a business and family relationship with controlling shareholders, members of the board of directors, and other commissioners as well as with the company itself.

In ensuring creation of good corporate governance, independent commissioners are required to have credibility, professionalism, and functional integrity. The existance of independent commissioners has been regulated by the indonesia stock exchangem namely inthe IDX board of directors decree No. 315/BEJ/06-2000 and disclosed in the IDX Board of Directors Decree No. 3015/BEJ/06-2000 that companies listed on the IDX must have an independent commissioners whose proportion is proportional to the number of shares owned by non- 
controlling shareholders. In the regulation, the minimum number of independent commissioners in a company is $30 \%$ of all members of the board of commissioners.

The first hypothesis regarding an independent board of commissioners with company performance is:

H1: The board of commissioners influences company performance

\subsection{Managerial Ownership}

Managerial ownership is the number of shares owned by management (manager). In companies with managerial ownership, managers who are at the same time shareholders will certainly align their interest asmanagers with their interest as shareholders. Managers who also become shareholders will increase the value of the company so that with ncreasing company value, the amount of his wealth as an individual shareholder will also icrease.

According to Faizal (2004), to indicate that there is a common interest between management and shareholders can be measured by the size of the number of managerial shareholdings in the company. The increasing proportion of managerial ownership, the better the performance of the company so that managers will be motivated to improve their performance for the company. Research conducted by Waskito (2014) stated that managerial ownership variables have a positive and significant effect on corporate performance variables. Based on the explanation above, a hypothesis can be formulated as follows:

H2: Managerial Ownership influences company performance

\subsection{Foreign Ownership}

Foreign ownership is the ownership of the number $\mathrm{f}$ shares owned by different parties, both individuals and institutions, to the shares of companies in Indonesia (Aryani, 2011). Regarding foreign ownership, in the Patibandla (2007) in Nuraeni (2010) examined companies using data 1989-1999, and showed the results that foreign ownership had a positive relationship with company performance, without accounting for companies for companies with unknown heterogeneity. Based on the descriptiion above, then a hypothesis can be formulated as follows:

H3: Foreign Ownership influences company performance

\subsection{Debt Financing}

Debt if alternative funding for companies. With the debt policy, it will be able to reduce agency. Payment of interest will reduce the company's total cash flow, so that debt can be seen a way to reduce agency conflict (Ahmad et al., 2012). In addtition, this alternative is also considered as a low-cost alternative. Said to be cheap, because the interest costs to be borne are less than the profits derived from the use of the debt (Deniansyah, 2009 in Prayudi, 2010). This tend to lead to company performance. Then the second hypothesis can be formulated:

H4: Financing debt influences company performance.

\subsection{Audit Quality}

De Angelo (1981) defines audit quality as the auditor's ability to find errors or fraud in the accounting system and pressure from clients to close books selectively even though fraud has been discovered. De Angelo also said that audit quality is related to independence and can be proxied by audit size. Ching et al., 2015 in his research concluded that high audit quality can contribute to the company's financial performance because public accounting firms with large sizes are always seen to have more top audit quality so as to increase investor confidence. Companies audited by one of the Big Four audit firms (a proxy for audit quality) are expected to have a better market for company performance and more transparency in financial reporting (Mitton, 2002 in Haat 2008).

Then a hypothesis can be formulated as follows:

H5: Audit Quality influences company performance

\subsection{Company Size}

The size of the company can provide economic benefits for the company and generate cash inflows for the company by operating assets reflected from the total assetes owned by the company (Im Manuella and Swandari, 2014). Large companies basically have greater financial strength in supporting performance, but on the other hand, comoanies are faced with more significant agency problems. Thus large companies can reduce the cost of producting low information compared to small companies. Where such reporting cannot necesarily be done without going through the excellent performance of the company.

H6: Company Size influences company performance

\subsection{Company Age}

Through the age of the company, investors can see whether a company is able to continue to survive and be able to compete in getting budinrdd opportunities (Sembiring, 2012). In Kamaliah, Akbar and Kinanti (2009) research, the age of a company is defined as the age from the company's establishment until the company is still able to 
carry out its operations. In addition, the age of the company also affects efficiency in carrying out its operational activities (Ang, Cole, and Lin, 2000). Then a hypothesis can be formulated as follows:

H7: Company Age influences company performance

\subsection{Research Model}

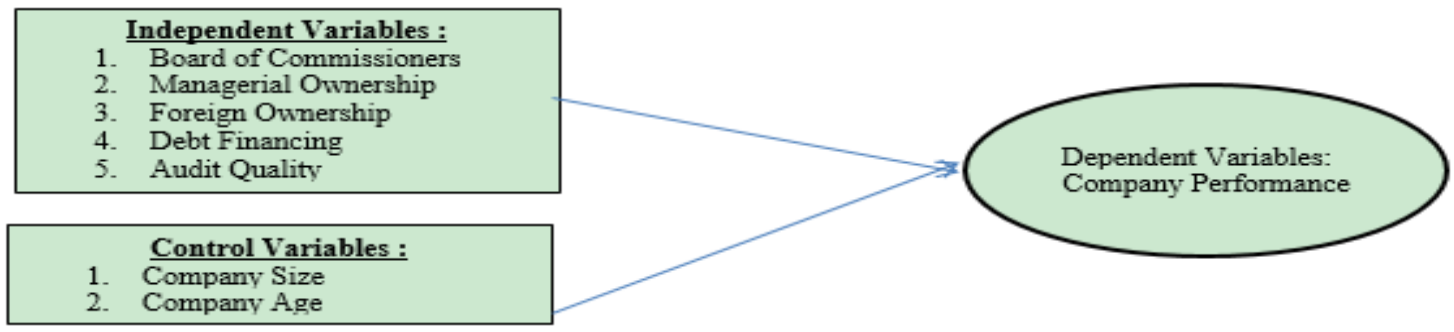

\section{Research Methods}

3.1 Population and Sample

The population in this study are manufactuing companies listed on the Indonesia Stock Exchange (IDX) for the period 2015-2018. The sample selection in this study was determined using purposive sampling, which is sampling based on specific criteria. Data used in this study were collected from the financial statements of companies listed in Indonesia Stock Exchange during the period 2015-2018 can be seen in www.idx.co.id

3.2 Data Analysis Method

The data analysis method used in this study is a quantitative data analysis method that is processed with the Statistical Package for Social Science (SPSS)

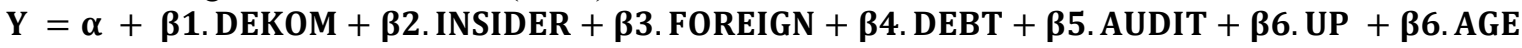

$$
+\varepsilon 1
$$

Where:

$\mathrm{Y}=$ Company Performance

$\mathrm{A}=$ Constant

$\mathrm{B} 1, \beta 2, \beta 3=$ Regression Coefficient

DEKOM $=$ Board of Commissioners

INSIDER = Managerial Ownership

FOREIGN = Foreign Ownership

DEBT $=$ Debt Financing

AUDIT $=$ Audit Quality

$\mathrm{UP}=$ Company Size

AGE $=$ Company Age

$\mathrm{E}=$ Error Rate

3.3 Variable Measurement

3.3.1 Board of Commissioners

$=\frac{\sum \text { Independent Commissioners }}{\sum \text { Company Commissioners }} \times 100 \%$

3.3.2 Managerial Ownership

$=\frac{\% \text { shares owned by management }}{\text { outstanding shares }}$

3.3.3 Foreign Ownership

$=\frac{\text { foreign ownership }}{\text { outstanding shares }} \times 100 \%$

3.3.4 Debt Financing

$=\frac{\text { Longterm Debt }}{\text { Total asset }}$

3.3.5 Audit Quality

Audit quality is expressed as a dummy variable, i.e. if a company uses Big 4 audit services equal to 1 and 0 if it does not use Big 4 audit services.

3.3.6 Company Size

The size of the company can be measured by the total assets of the company. Determinants of company size are based on total assets.

3.3.7 Company Age

The natural logarithm of the number of years since the company was founded. 


$$
\begin{aligned}
& \text { 3.3.8 Company Performance (Tobin's Q) } \\
& =\frac{\text { Market Shares Value }+ \text { Long term debt }}{\text { Total asset }} \times 100 \%
\end{aligned}
$$

\section{Result and Discussion}

\subsection{Test of Normality with Skewness and Kurtosis}

This test aims to test whether, in the regression model, dependent variable, independent variables, or both are normally distributed or not. A good regression model is standard data or normal detecting. The normality test with skewness and kurtosis can be seen in table 1 .

Table 1. Test of Normality

\section{Descriptive Statistics}

\begin{tabular}{lr|r|r|r|r} 
& \multicolumn{2}{c}{ N } & \multicolumn{2}{c}{ Skewness } & \multicolumn{2}{c}{ Kurtosis } \\
& Statistic & Statistic & Std. Error & Statistic & \multicolumn{1}{c}{ Std. Error } \\
\hline DEKOM & 325 & 1.116 & .135 & .135 & .270 \\
\hline INSIDER & 32 & -.947 & .414 & -.578 & .809 \\
\hline FOREIGN & 325 & 1.203 & .135 & -.032 & .270 \\
\hline DEBT & 324 & 1.322 & .135 & 2.793 & .270 \\
\hline AUDIT & 325 & .306 & .135 & -1.918 & .270 \\
\hline UP & 324 & 1.130 & .135 & -.029 & .270 \\
\hline AGE & 321 & -1.453 & .136 & 1.110 & .271 \\
\hline TOBINS'Q & 325 & 2.374 & .135 & 7.322 & .270 \\
\hline Valid N (listwise) & 32 & & & & \\
\hline Informan
\end{tabular}

Information: DEKOM (Board of Commissioners); INSIDER (Managerial Ownership); FOREIGN (Foreign Ownership); DEBT (Debt Financing); AUDIT (Audit Quality); UP (Company Size); Age (Company Age); TOBIN'S Q (Company Performance)

\subsection{Test of Multicollinearity}

The multicollinearity test has several provisions where the provisions of VIF are if VIF $>10$, then there is multicollinearity. But if $\mathrm{VIF}<10$, then there is no multicollinearity. The test results are :

Table 2. Test of Multicollinearity

\begin{tabular}{ll|r|r}
\hline \multirow{2}{*}{ Model } & & \multicolumn{2}{c}{ Collinearity Statistics } \\
Tolerance & VIF \\
\hline 1 & & & \\
\cline { 2 - 4 } & (Constant) & .175 & 5,714 \\
\cline { 2 - 4 } & DEKOM & .716 & 1,397 \\
\cline { 2 - 4 } & INCIDER & .699 & 1,431 \\
\hline & FOREIGN & .116 & 8,593 \\
\hline & DEBT & .355 & 2,814 \\
\hline & AUDIT & 642 & 1,557 \\
\hline & UP & 672 & 1,488 \\
\hline
\end{tabular}

Based on the table above, the results of the tolerance value calculation do not show that there is an independent variable that has a tolerance value $<0.1$ and none of the variables has a VIF $>10$. So it can be concluded that there is no correlation between the independent variables or multicollinearity does not occur.

\subsection{Descriptive Statistics}

Table 3. Descriptive Statistic

\section{Descriptive Statistics}

$\mathrm{N}$ Minimum Maximum The mean Std. Deviation

\begin{tabular}{lr|r|r|r|r|r}
\hline DEKOM & 325 & .25 & 1.00 & .5968 & 197789 \\
\hline INCIDER & 32 & .76 & 1.57 & 1.2858 & .28086 \\
\hline FOREIGN & 325 & .00 & .93 & 1956 & 29732 \\
\hline DEBT & 324 & -2.22 & 8.29 & -.0885 & 1.42410 \\
\hline AUDIT & 325 & .00 & 1.00 & .4246 & .49505 \\
\hline UP & 324 & .00 & 12.41 & 3.4737 & 3.70471 \\
\hline AGE & 321 & .48 & 1.61 & 1.2724 & 266110 \\
\hline TOBINS'Q & 325 & .12 & 3.35 & .7168 & .48690 \\
\hline Valid N (listwise) & 32 & & & & \\
\hline
\end{tabular}


The table above provides information about the descriptive variable data being tested. From this table, it can be seen that the average number of companies included in the group of manufactuting companies that were sampled in the research of the Board of Commissioners amounted to 59.68\% of the Board of Commissioners. While the standard deviation for the board of commissioners is 0.19789 .

The variable structure of managerial ownershipp of companies in Indonesia is concentrated ownership where there are controlling shareholders in a company. Of the companies sampled in this study on average $1.2858 \%$ of the company had managerial ownership.

Variable foreign ownership measured by the proportion of shares to outstanding shares owned by instituions has an average value of $19.56 \%$ and iwth a standard deviation of 0.29732 .

Variable debt financing as measured by long-term debt divided by total assets of the company has an average value of $8.85 \%$.

For audit quality variables measured using dummy variables, the average audit quality is $42.46 \%$, the minimum value of this audit quality is 0 and the maximum value is 1.00 .

Variable size of the company measured by the total assets then the average size of the company is $3.4737 \%$, with a standard deviation of 3.70471 .

Table 4. presents the pearson correlation matrix of thevariables studied. The table is presented as follows :

Table 4. Correlation

Correlations

\begin{tabular}{l|l|l|l|l|l|l|l|} 
DEKOM & INCIDER & FOREIGN & DEBT & AUDIT & UP & AGE & TOBINS'Q \\
\hline
\end{tabular}

\begin{tabular}{|c|c|c|c|c|c|c|c|c|c|}
\hline \multirow[t]{3}{*}{ DEKOM } & $\begin{array}{l}\text { Pearson } \\
\text { Correlation }\end{array}$ & 1 & .388 & .023 & -.025 & .024 & .004 & -.032 & .153 \\
\hline & Sig. (2-tailed) & & .028 & 679 & 659 & 661 & .946 & .567 & .006 \\
\hline & $\mathrm{N}$ & 325 & 32 & 325 & 324 & 325 & 324 & 321 & 325 \\
\hline \multirow[t]{3}{*}{ INCIDER } & $\begin{array}{l}\text { Pearson } \\
\text { Correlation }\end{array}$ & .388 & 1 & -.146 & .254 & -.009 & -.006 & -.007 & .345 \\
\hline & Sig. (2-tailed) & .028 & & .426 & .160 & .959 & 974 & .971 & .053 \\
\hline & $\mathrm{N}$ & 32 & 32 & 32 & 32 & 32 & 32 & 32 & 32 \\
\hline \multirow[t]{3}{*}{ FOREIGN } & $\begin{array}{l}\text { Pearson } \\
\text { Correlation }\end{array}$ & .023 & -.146 & 1 & .067 & .202 & -.014 & .013 & -.111 \\
\hline & Sig. (2-tailed) & 679 & .426 & & .227 & .000 & .802 & .811 & .045 \\
\hline & $\mathrm{N}$ & 325 & 32 & 325 & 324 & 325 & 324 & 321 & 325 \\
\hline \multirow[t]{3}{*}{ DEBT } & $\begin{array}{l}\text { Pearson } \\
\text { Correlation }\end{array}$ & -.025 & .254 & .067 & 1 & .000 & .043 & -.017 & .195 \\
\hline & Sig. (2-tailed) & 659 & .160 & .227 & & 1,000 & .444 & 759 & .000 \\
\hline & $\mathrm{N}$ & 324 & 32 & 324 & 324 & 324 & 323 & 320 & 324 \\
\hline \multirow[t]{3}{*}{ AUDIT } & $\begin{array}{l}\text { Pearson } \\
\text { Correlation }\end{array}$ & .024 & -.009 & .202 & .000 & 1 & .977 & -061 & -.032 \\
\hline & Sig. (2-tailed) & 661 & .959 & .000 & 1,000 & & .081 & 279 & .561 \\
\hline & $\mathrm{N}$ & 325 & 32 & 325 & 324 & 325 & 324 & 321 & 325 \\
\hline \multirow[t]{3}{*}{ UP } & $\begin{array}{l}\text { Pearson } \\
\text { Correlation }\end{array}$ & .004 & -.006 & -.014 & .043 & .977 & 1 & .018 &,- 055 \\
\hline & Sig. (2-tailed) & .946 & 974 & .802 & .444 & .081 & & .748 & 322 \\
\hline & $\mathrm{N}$ & 324 & 32 & 324 & 323 & 324 & 324 & 321 & 324 \\
\hline \multirow[t]{3}{*}{ AGE } & $\begin{array}{l}\text { Pearson } \\
\text { Correlation }\end{array}$ & -.032 & -.007 & .013 & -.017 & -061 & .018 & 1 & -.057 \\
\hline & Sig. (2-tailed) & .567 & .971 & .811 & 759 & 279 & .748 & & .308 \\
\hline & $\mathrm{N}$ & 321 & 32 & 321 & 320 & 321 & 321 & 321 & 321 \\
\hline \multirow[t]{3}{*}{ TOBINS'Q } & $\begin{array}{l}\text { Pearson } \\
\text { Correlation }\end{array}$ & .153 & .345 & -.111 & .195 & -.032 &,- 055 & -.057 & 1 \\
\hline & Sig. (2-tailed) & .006 & .053 & .045 & .000 & .561 & 322 & .308 & \\
\hline & $\mathrm{N}$ & 325 & 32 & 325 & 324 & 325 & 324 & 321 & 325 \\
\hline
\end{tabular}

From the output table above we know the value of Sig. (2-tailed) between DEKOM and TOBIN'S Q is $0.006<0.05$, which means that there is a significant correlation between DEKOM variables and TOBIN'S Q.

From the output table above we know the value sig. (2-tailed) between INSIDER and TOBIN'S Q is $0.053>0.05$, which means there is no significant correlation between INSIDER variables and TOBIN'S Q.

From the output table above we know the value sig. (2-tailed) between FOREIGN and TOBIN'S Q is $0.045<0.05$, which means there is a significant correlation between DEBT and TOBIN'S Q variables. 
From the output table above we know the value sig. (2-tailed) between DEBT and TOBIN'S Q is $0.000<0.05$, which means there is a significant correlation between DEBT and TOBIN'S Q variables.

From the output table above we know the value sig. (2-tailed) between AUDIT and TOBIN'S Q is 0.844>0.05, which means there is no significant correlation between AUDIT variables and TOBIN'S Q.

From the output table above we know the value sig. (2-tailed) between UP and TOBIN'S Q is $0.561>0.05$, which means there is no significant correlation between UP Variables and TOBIN'S Q.

\subsection{Coefficient of Determination $\left(\mathrm{R}^{2}\right)$}

The coefficient of determination used the ability to measure the model in explaining the variation of independent variables. The following results the calculation of the hypothesis determination coefficient.

Table 5. Coefficient of Determinantion

\begin{tabular}{lc|r|r|r} 
Model & R & R Square & $\begin{array}{c}\text { Summary Model } \\
\text { Adjusted R Square }\end{array}$ & Std. Error of the Estimate \\
\hline 1 & $.778^{\text {a }}$ & 605 & .489 & 2592 \\
\hline
\end{tabular}

a. Predictors: (Constant), AGE, INCIDER, UP, AUDIT, FOREIGN, DEKOM, DEBT

Based on the table, the cofficient of determination in the regression models get the value of adjusted $\mathrm{R}^{2}$ of 0.592. this means that $59.2 \%$ of variation in Company Performance can be explained by the board of commissioners, managerial ownership, foreign ownership, debt financing, audit quality, company size, company age while the rest can be explained by factors other than the independent variable.

4.5 Research Result and Discussion

Table 6. Result

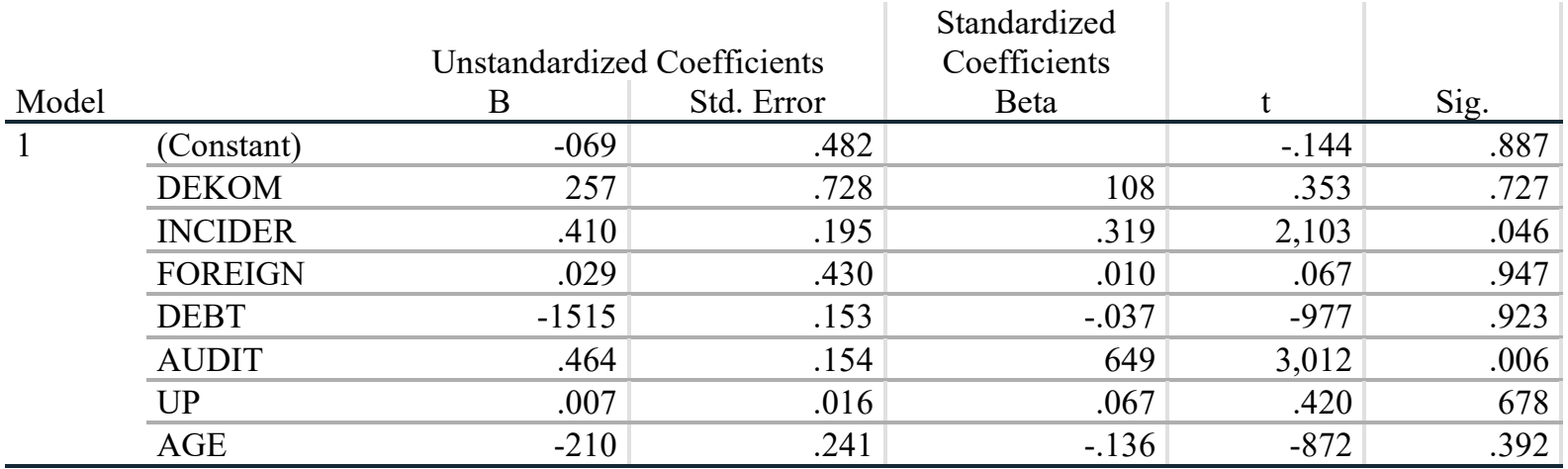

Information: DEKOM: Board of Commissioners; INCIDER: Managerial Ownership; FOREIGN: Foreign Ownership; DEBT: Debt Financing; AUDIT: Audit Quality; UP: Company size; AGE: Company Age TOBINS'Q: Company Performance

The Effect of the Board of Commissioners on Company Performance

The hypothesis test table above gives a sign value. DEKOM of 0, 727 >0.05, meaning that DEKOM has no effect on TOBINS'Q . This shows that with the large number of members of the board of commissioners, it allows companies to get less performance higher. Through the role of the board of commissioners can carry out the oversight function of the company's operations by the management, then from the total membership of the board of commissioners can provide oversight of the results of the company's operational processes. So the first hypothesis (H 1 ) is rejected.

\section{The Effect of Managerial Ownership on Company Performance}

For INSIDER the above hypothesis gives a sign value of $0.046<0.05$ meaning that INSIDER has an effect on

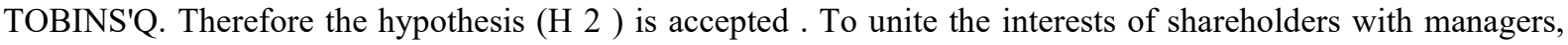
management of ownership is used. The more the proportion of managerial ownership increases, the better the performance of the company. This is because the conditions in Indonesia, where the proportion of managerial ownership in the company is still very low, so as to help bring together the interests between managers and owners do application of managerial ownership in order to motivate managers to take steps to increase company performance um can run it effectively.

\section{The Effect of Foreign Ownership on Company Performance}

Based on testing the second hypothesis to get the results that the FOREIGN variable gives the value of the sign. 0 , $947>0.05$ means that FOREIGN has no effect on TOBINS'Q. then H 3 is rejected. These results make it clear that foreign owners have not been able to implement good corporate governance like foreign companies in general and in the case of foreign owners do not carry out strict supervision of management in running the company, so this has an impact on company performance. Another reason is due to the low composition of foreign ownership in local companies, so that foreign shareholders have less influence in terms of decision making and supervision. 


\section{The Effect of Debt Financing on Company Performance}

The results of this study indicate that DEBT has no effect on TOBINS'Q. This can be seen from the results of the t test obtained, indigo i sign. 0,923 $>0.05$ which means that it is not significant. The results of this study are supported by Sofyaningsih and Hardinigsih (2011) who state that the debt policy on company performance because the sources of corporate funds in the form of debt and capital have weaknesses and shortcomings so that the source of funds is only adjusted by a number of business climate, interest incurred due to debt or returns expected by shareholders. S ehingga hypothesis to four (H4) is rejected.

\section{The Effect of Audit Quality on Company Performance}

Seen in Table 4, Which shows that the audit quality variable has a value of sig. 0.006 is smaller than the value probabilitas 0.05 or 0.00 value $6<0.05$, which means that audit quality significantly affect the performance of the company. So H5 accepted. In line with agency theory that one way to reduce conflicts of interest between principals and agents is done by improving audit quality by Big4 KAP audit services that will have market trust. The results of this study are in line with the results of previous studies that show a positive relationship between audit quality and company performance, such as Lennox (1999) which proves that auditors from big eight accounting firms are more accurate than auditors from non big 4 accounting firms .

\section{The Effect of Company Size on Company Performance}

The hypothesis test table above gives a sign value. UP of $0,678>0.05$, meaning that UP has no effect on TOBINS'Q. This result is not in line with research conducted by (Tisna and Agustami, 2016) which states that the size of the company's positive effect on the company's performance. So the first hypothesis ( H 6 ) is rejected . The condition is probably caused by the use of assets that are not optimal so they are not able to improve performance. Companies that have great financial strength basically can support performance, but on the other hand, large companies are also faced with a bigger agency problem because it is more difficult to monitor.

\section{The Effect of Company Age on Company Performance}

Baed seventh hypothesis testing shows that AGE variable results that have been of value sign. At $0,392>0.05$ means AGE has no affect the TOBINS'Q then H7 rejected. This finding supports the research of Stephen D Smith, et al (1996) in which the longer the company's life span and the company's experience turned out to have diverse performance, some were better and some were not.

\section{Conclusion, Limitations and Recomendation}

Based on the results of hypothesis testing from data analysis, it can be concluded as follows: The data used in this study are normally distributed, there is no multicollinearity. The test results show that of the seven variables namely the board of commissioners, managerial ownership, foreign ownership, debt financing, and audit quality only audit quality variables that affect company performance while company size and age variables cannot be a control variable on company performance.

This study has limitations, namely: this study took a sample of companies included in manufacturing companies on the Indonesian Stock Exchange with a year of observation from 2015 to 2018, so the results of the study have not been able to provide broader generalization power to other insurance sectors.

Based on the limitations of the study as described above, the following are some suggested improvements for future researchers. (1) the next researcher is expected to be able to increase the scope of the research sample in order to provide research results that provide stronger and better generalizations. (2) The next researcher is expected to test other variables that are relevant to the company's performance.

\section{References}

Ahmad, Abdullah and Roslan, 2012, Capital Structure Effect on Firms Performance: Focusing on Con-sumers and Industrials Sectors on Malaysian

Ang, JS, Cole, RA, and Wuh Lin, J. 2000. Agency Costs and Ownership Structure. The Journal of Finance 55: 81106.

Aryani, Etha Rizki. 2011. The Effect of Good Corporate Governance and Ownership Structure on Agency Cost. Thesis of Faculty of Economics, Diponegoro University, Semarang.

Boediono, G SB 2005. "Profit Quality: Study of the Effect of Corporate Governance Mechanisms and the Impact of Profit Management by Using Path Analysis," National Symposium on Accounting VIII, Sebelas Maret University, Surakarta.

Che Haat, Moh Hasan et.al (2008), Corporate Governance, Transparency and Performance of Malaysian Companies, Malaysian of Auditing Journals, Vol. 23 No. 8

Ching, CP, Tea, BH, San, OT and Hoe, HY (2015), "The relationship between audit quality, earnings management, and financial performance of Malaysian public listed companies", International Journal of Economics \& Management, Vol. 9 No. 1, pp. 211-229.

DeAngelo, LE (1981), "Auditor size and audit quality", Journal of Accounting and Economics, Vol. 3, pp. 18399. 
Faizal. 2004. Analysis of Agency Costs, Ownership Structure, and Corporate Governance Mechanisms. National Seminar on Accounting. Padang

FCGI, 2001, Corporate Governance Series, 2nd Edition Jakarta.

Hassan, MH and SS Halbouni. 2013. Corporate Governance, Economic Turbulence and Financial Performance of UAE Listed Firms. Studies in Economic and Finance. Vol. 30, No. 2, pp. 118-138

Hastuti, YW2011. "The Effect of Internal and External Corporate Governance Mechanisms on Financial Performance: Case Study in Banks Registered in BEI 2006-2009". Thesis Not Published. Faculty of Economics and Business, Diponegoro University.

Herawaty, Vinola. 2008. The Role of Corporate Governance Practices as a Moderating Variable of the Effects of Earning Management on Company Value . Journal of Accounting and Finance, Vol. 10 No. 2, November, 2008, pp. 97-108

Hidayah, E. (2008). The Effect of Information Disclosure Quality on the Relationship Between the Implementation of Corporate Governance and Company Performance on the Jakarta Stock Exchange. Thesis. Indonesian Islamic University.

Imadudin, Z. Swandari and Redawati. 2014. " Effect of capital structure on company performance". Journal of management insights, Vol. 2, Number 1.

Immanuella, I (2014). Effect of Ownership, Managerial Capital Structure, Company Size and Agency Cost as Intervening Variables on Company Performance in Manufacturing Companies Listed on the IDX. Widya Warta, ISSN 0854-1981, NO.1, Page: 59-70

Jensen, MC and Meckling, WH (1976), "Theory of the fi rm: managerial behavior, agency costs and ownership structure", Journal of Financial Economics, Vol. 3, pp. 303-60.

Juwitasari, Ruth. (2008). "Influence of Independence, Frequency of Meetings and Remuneration of the Board of Commissioners on the Value of Companies Registered in the IDX in 2007" S2 Thesis, Faculty of Economics, University of Indonesia

Keasey, K., Thompson, S. and Wright, M., (1997) Corporate Governance: Economic, Management and Financial Issues, Oxford University Press

Kamaliah, Nasrizal Akbar and Lexinta Kinanti . 2009. Analysis of the effect of activity ratio, financial leverage, size, and age of the company on the profitability of wholesale and retail trade companies listed on the Indonesian stock exchange. Accounting Department, Faculty of Economics, University of Riau .

National Governance Policy Committee (KNKG). 2006. General Guidelines for Good Corporate Governance in Indonesia. Jakarta. D iakses dated January 12, 2013.

Meutia, Inten. (2004), "The Effect of Auditor Independence on Profit Management for Big-5 and Non-Big-5 KAP". Indonesian Accounting Research Journal. 7 (3), 333-350.

Millstein, IM 1999, Introduction to the Report and Recommendations of the Blue Ribbon Committee on Improving the Effectiveness of Corporate Audit Committees, The Busine s Lawyer, 54 (May): 1057-1066.

Murhadi, Werner R. 2009. Good Corporate Governance and Earning Management, Practices: An Indonesian Cases

Nur'aeni, Dini. 2010. The Effect of Share Ownership Structure on Company Performance, Thesis: Faculty of Economics, Diponegoro University

Purno, B Listyo. And Khafid, Muhammad. 2013. "The Effect of Good Corporate Governance Mechanisms on Banking Performance". National Accounting Symposium XVI, 25-28 September 2013. Manado

Purwantini, V. Titi. 2011. Effect of Good Corporate Governance Mechanisms on Company Value and Corporate Financial Performance (Study of Manufacturing Companies Listed on the IDX). STIE AUB Surakarta.

Randal J. Elder, Mark S. Beasley, Alvin A. Arens, Amir Abadi Jusuf. (2011). Audit and Assurance Services, Jakarta: Salemba Empat.

Sembiring, ER (2012 ). Company Characteristics and Disclosure of Social Responsibility: Study of Companies Listed on the Jakarta Stock Exchange. Diponegoro Semarang Maksi Journal of Ubaya, 6, 69-85.

Sofyaningsih, S. and P. Hardiningsih. 2011. "Ownership Structure, Dividend Policy, Debt Policy and Corporate Value". Journal of Financial and Banking Dynamics, Vol. III, No. 1, h. 68-87.

Soliha, Euis and Taswan. 2002. The Effect of Debt Policy on Company Value and Several Factors that Influence it. Journal of Business and Economics, Vol.9, No.2.

Sudiyanto, B. and Puspitasari, E. 2010. Tobin's Q and Altman Z-Score as Indicators of Measuring Company Performance. Accounting Study, February 2010, 2 (1): h: 9-21.

Trisnantari, Ayu Novi., 2012 , "the influence of corporate governance on the relationship of the replacement of chief executive officer with company performance", Thesis of Udayana University, Denpasar.

Waskito, Titis. 2014. The Effect of Managerial Ownership Structure, Institutional Ownership, and Company Size on Financial Performance (Judging from Manufacturing Companies Listed on the Indonesia Stock Exchange in 2008 to 2011. Manuscript of Publications of the Bachelor Program in the Faculty of Economics and Business, Muhammadiyah University, Surakarta. 
Weston, FJ, and Brigham, EF, 1993. Fundamentals of Financial Management, Volume 2, Ninth Edition, Translation by Alfonsus Sirait, Jakarta: Erlangga.

Wiranata, Yulius Ardy and Yeterina Widi Nugrahanti. 2013, "Effect of Ownership Structure on Manufacturing Company Profitability in Indonesia". Journal of Accounting and Finance, Vol. 15 No.1, pp. 15-26 